\title{
Development of Gluten-Free Bread baked with Yam Flour
}

\author{
Masaharu Seguchi $^{1 *}$, Miki Ozawa ${ }^{2}$, Chieko Nakamura $^{2}$ and Aya Tabara ${ }^{1}$ \\ ${ }^{1}$ Faculty of Home Economics, Laboratory of Food Technology, Kobe Women's University, Suma-Ku, Kobe City 654-8585, Japan \\ ${ }^{2}$ Kobe Women's Junior College, Chuoo-Ku, Kobe City 650-0046, Japan
}

Received January 5, 2012; Accepted March 14, 2012

\begin{abstract}
Gluten-free bread baked with yam flour (Jinennjyo; Dioscorea japonica), wheat starch, sugar (sucrose), compressed yeast, and water showed similar bread making properties, such as bread height $(\mathrm{mm})$ and specific volume $\left(\mathrm{cm}^{3} / \mathrm{g}\right)$, to that of wheat bread. Yam flour was dialyzed against water and separated into nondialyzable (high-molecular-weight (HMW)) fraction and dialyzable (low-molecular-weight (LMW)) fractions. The fractions were dried and used separately in bread making in the same manner. The results indicated that the HMW or LMW fractions showed poor bread making properties when used individually, whereas bread baked with a mixture of the HMW and LMW fractions exhibited good bread making properties. Next, the LMW fraction was separated into peptide and sugar subfraction by paper chromatography. Addition of the peptide subfraction to the HMW fraction resulted in better bread making properties than addition of the sugar subfraction.
\end{abstract}

Keywords: gluten-free bread, yam flour, wheat flour, celiac disease (CD)

\section{Introduction}

Celiac disease (CD) is a severe disease characterized by chronic diarrhea, stunting, anemia, and increased mortality (Catassi and Yachha, 2009). In countries populated by individuals of European origin, CD affects approximately $1 \%$ of the general population. In many developing countries the frequency of $\mathrm{CD}$ is likely to increase in the near future, given the widespread tendency to adopt a Western, gluten-rich diet. Toxicity related to trace levels of gluten $(10-50 \mathrm{mg}$ daily) in a celiac diet has been reported (Catassi and Fasano, 2008). With the availability of improved and more accessible diagnostic tools, $\mathrm{CD}$, in both children and adults, is now more frequently recognized in many countries.

Rice is the traditional staple food in Japan. However, the Japanese have recently come to prefer wheat and barley products such as bread, cake, noodle, and alcoholic beverages such as beer. There may be people who suffer from CD in Japan, which could be alleviated by changing eating habits from a Western to a Japanese diet. While the prevalence of $\mathrm{CD}$ in Japan is unclear, the tendency of younger people to prefer western food may exacerbate the problem in Japan.

Yam flour, which is popular in Japan as a viscous food

*To whom correspondence should be addressed.

E-mail: seguchi@suma.kobe-wu.ac.jp material and is used in Japanese cakes such as manjyu and karukan, was selected in this study to produce a new glutenfree bread. Japanese people generally like to eat mashed yam (tororo) with hot baked rice (Tsukui et al., 2001). Yam is nutritious and improves digestion (Tsukui et al., 2005). Yam contains high levels of fiber and potassium (12 mg/100 g), and is thought to have antioxidant activity (Hou et al., 2002), making it effective in preventing cancer of the large bowel (Miyoshi et al., 2011), hypertension (Nozawa et al., 2005), and diabetes (Omoruyi, 2008).

There are approximately 600 species of yam around the world, three of which three, Dioscorea japonica, Dioscorea batatas, and Dioscorea alata, are popular in Japan. Locally called Jinennjyo, Dioscorea japonica is specific to Japan (Yoshida et al., 1976) and characterized by its high viscosity. Tsukui (2003) and Tsukui et al. (2005) reported that yams contain $5-15 \%$ polysaccharides and $84-95 \%$ glycoproteins, and the viscous components in yam can be fractionated to mannan (MW; more than $2,000 \times 10^{3}$ ) and glycoprotein $\left(\mathrm{MW} ; 400 \times 10^{3}\right)$. The polysaccharide fraction in the glycoprotein is composed of galactose, mannose, glucose, and arabinose, whereas the protein fraction contains aspartic acid, glycine, and arginine. However, a high viscosity yam flour/water combination has not been previously described.

The objectives of this study were to determine whether 
yam flour could be substituted for wheat flour in bread making, and to assess the effect of the HMW fraction and the LWM peptide subfraction on bread making performance.

\section{Materials and Methods}

Materials Four kinds of yam (Dioscorea japonica I (Jinennjyo), D. japonica II (Yamanoimo), Dioscorea batatas I (Yamatoimo), D. batatas II (Nagaimo)) were used in this experiment. The yams were purchased from a commercial source. The yams were washed, peeled with a knife, crushed in the $1,500 \mathrm{~mL}$ receptacle of a Waring blender for $10 \mathrm{~min}$ at $5,000 \mathrm{rpm}$, and freeze-dried for $70 \mathrm{~h}$ in a Kyowa freeze-drier RLE-120 (Kyowa Vacuum Engineering Co., Ltd., Tokyo, Japan). Moisture, protein, and ash contents were measured (Table 1). Each dried sample was crushed into flour with a mortar and pestle, and stored in a freezer until use. Nagata Sangyo Co. Ltd. (Hyogo, Japan), donated a wheat starch sample. Protein, ash and moisture contents in the wheat starch sample were $0.15,0.13$, and $10.7 \%$, respectively. The wheat starch sample was selected for use in this experiment, as explained below. Wheat starch granules are known to contain minor components such as non-starch polysaccharides, proteins such as friabilin, and lipids (Galliard et al., 1989). Lipids and proteins at the surface of starch granules have been implicated in the behavior of starch with respect to pasting properties, wetting and dispersion, and starch suspension stability (Galliard et al., 1989). Moisture content was determined according to Tsutsumi and Nagahara (1961). Protein conversion was carried out using the formula $\mathrm{N} \times$ 5.7 (Approved Methods 46-10, AACC International 2000). Ash was determined according to the AACC International Method (08-01, 2000) at 14.0\% m.b.

Bread baking For baking bread with yam flour, a method was developed to achieve bread similar to that obtained with wheat flour. To obtain the same bread making properties (bread height $(\mathrm{mm})$ and specific volume $\left(\mathrm{cm}^{3} / \mathrm{g}\right)$ ) as those of wheat flour, it was determined that the total amount of water added and mixing time should be $30 \mathrm{~mL}$ and $18 \mathrm{~min}$, respectively. Details regarding the baking method for one loaf were as follows: yam flour (10 g), sugar (8.86 g), and compressed yeast $(10 \mathrm{~g}) / 10 \mathrm{~mL}$ of water were mixed in a $3.6 \mathrm{~L}$ bowl using a kitchen aid mixer (Kenmix Chef Aicoh Mixers and Aicoh Systems Co., Ltd., Japan) for 9 min at $116 \mathrm{rpm}$. Wheat starch $(30 \mathrm{~g})$ and water $(20 \mathrm{~mL})$ were added, and the mixture was further homogenized for $9 \mathrm{~min}$ at the same speed. The entire homogenized dough, composed of yam flour 10 $\mathrm{g}$, wheat starch $30 \mathrm{~g}$, sugar $8.86 \mathrm{~g}$, compressed yeast $10 \mathrm{~g}$, and water $30 \mathrm{~mL}$ was placed into a pan $\left(5.5 \times 9.5 \times 6.6 \mathrm{~cm}^{3}\right)$, proofed in an oven at $40^{\circ} \mathrm{C}$ for $20 \mathrm{~min}$, and baked at $210^{\circ} \mathrm{C}$ for $10 \mathrm{~min}$ in an oven (Sanyo Drying Oven MOV-212, Sanyo Co. Ltd., Japan). After baking, the bread was removed from the pan and cooled for $1 \mathrm{hr}$ at room temperature $\left(26^{\circ} \mathrm{C}\right)$ with a relative humidity of $43 \%$. Bread height $(\mathrm{mm})$, weight $(\mathrm{g})$, and volume $\left(\mathrm{cm}^{3}\right)$ were measured, and crumb grains were evaluated visually. The color ( $L, a$, and $b$ values) of the breadcrumb was evaluated using an $L, a$, and $b$ color specification system chromaticity diagram and a Hunter Lab Color Meter NE 2000 (Nippon Denshoku Co., Ltd., Tokyo, Japan). Positive values for $L, a$, and $b$ indicate white, red, and yellow, respectively.

Dialysis of yam flour/water suspension A dialysis tube (diameter $=21.4 \mathrm{~mm}$ ) (Nihon Medical Science Co., Ltd., Takasaki, Japan) was used to dialyze 10 grams of yam ( $D$. japonica) (Jinennjyo) flour suspended in $150 \mathrm{~mL}$ of water against $10 \mathrm{~L}$ of water overnight in a cold room $\left(4^{\circ} \mathrm{C}\right)$. The nondialyzable fraction (in the dialysis tube), composed of starch, polysaccharides, and proteins, was freeze-dried at $-15^{\circ} \mathrm{C}$ and crushed; this was termed the HMW fraction. The dialyzable fraction, mainly composed of peptides and sugars, was concentrated to a syrup at $65^{\circ} \mathrm{C}$ using a Rotary Evaporator (RE-51, Yamato Scientific Co., Ltd., Tokyo, Japan) and termed the LMW fraction. To determine the effect of potassium on bread making properties, the LMW fraction was placed in a Yamato Electric Furnace Model FA-21 (Yamato Scientific Co., Ltd., Tokyo, Japan) at $600^{\circ} \mathrm{C}$ for $36 \mathrm{~h}$, and the obtained ash was suspended in water. Before bread baking, the $\mathrm{pH}$ of the ash suspension was adjusted to 7.0 with acetic acid.

Paper chromatography (PC) of the LMW fraction Thin paper No. 50 (Advantec Toyo Co., Ltd., Tokyo, Japan) was

Table 1. General analysis of yam flour.

\begin{tabular}{cccc}
\hline Yam flour & Moisture content (\%) & Crude protein (\%) & Ash (\%) \\
\hline Dioscorea japonica I (Jinennjyo) & $1.4(0.21)$ & $8.7(0.14)$ & $3.6(0.07)$ \\
Dioscorea japonica II (Yamanoimo) & $0.0(0.00)$ & $10.7(0.00)$ & $4.2(0.00)$ \\
Dioscorea batatus I (Yamatoimo) & $0.5(0.07)$ & $11.5(0.07)$ & $4.7(0.21)$ \\
Dioscorea batatus II (Nagaimo) & $6.2(5.23)$ & $9.0(0.14)$ & $4.8(0.00)$ \\
\hline
\end{tabular}

Values represent means of two replicates with SD in parentheses. 
used for qualitative analysis. PC of the LMW fraction was performed using a solution (pyridine/1-butanol/water $=4: 6: 3$ $(\mathrm{v} / \mathrm{v}))$ in a cabinet $\left(33 \times 70 \times 72 \mathrm{~cm}^{3}\right)$ (Toyo Seisakusho Co., Ltd., Tokyo, Japan) at $20-30^{\circ} \mathrm{C}$. Sample solutions spotted and dried on the filter paper were ascended twice. An aniline hydrogen phthalate (AHP) solution, for sugar visualization, was sprayed on the dried filter paper. Yellow-brown spots (sugars) were visualized by heating at $160^{\circ} \mathrm{C}$ for $2-3 \mathrm{~min}$. Ninhydrin solution $(100 \mathrm{mg} / 50 \mathrm{~mL}$ ethanol), for peptide visualization, was sprayed on the dried filter paper and allowed to stand at room temperature. Peptides were visualized as red-purple spots.

Separation of the LMW fraction into peptide and sugar subfractions by a PC PC was performed as described above. Thick filter paper (No. 590) $\left(60 \times 60 \mathrm{~cm}^{2}\right)$ was used for quantitative fractionation. The LMW fraction $(1.1 \mathrm{mg})$ spotted on filter paper was ascended twice. The visualization of peptides and sugars, using ninhydrin and AHP solutions, in guide strips cut from the same paper indicated the positions of the main peptide and sugar subfractions. These subfractions were isolated from the paper by chromatographic extraction with water, and concentration into a syrup using a rotary evaporator.

Mixograph tests of yam flour, HMW fraction, and LMW fraction The mixograph test of yam flour was performed in a 10-g mixograph (National MFG Company, NE, USA) according to the method of Nakamura et al. (2008). Ten grams each of yam flour, HMW fraction, and LMW fraction in $5.5 \mathrm{~mL}$ of water were compared to wheat flour $(10 \mathrm{~g})$ and water (5.0 $\mathrm{mL}$ ). The mixing speed of the mixograph was set to $86 \mathrm{rpm}$.

Statistical Analysis The SPSS statistical software package (SPSS Inc., Chicago, IL, USA) was used for the statistical analyses. Two loaves of bread were baked in each experiment. Bread height $(\mathrm{mm})$ and specific volume $\left(\mathrm{cm}^{3} / \mathrm{g}\right)$ were measured twice for each sample and averaged. Data with significant $F$ values were subjected to analysis of variance, followed by Duncan's multiple range test for comparison of means.

\section{Results and Discussion}

Bread making with yam dough Good bread making properties, such as bread height $(\mathrm{mm})$ and specific volume $\left(\mathrm{cm}^{3} / \mathrm{g}\right)$, are important characteristics of typical bread, and the goal is to obtain gluten-free bread making properties that are typical of wheat bread. The bread making properties of bread baked with yam flour were compared with those of bread baked with wheat flour. Seguchi and Abe (2004) reported that bread baked with wheat flour (Haruyutaka wheat flour), sugar, salt, compressed yeast, and water showed a typical bread height of $69.4 \mathrm{~mm}$ and a specific volume of 3.45 $\mathrm{cm}^{3} / \mathrm{g}$. In this experiment, bread was baked using flour from four kinds of yam (D. japonica I (Jinennjyo), D. japonica II (Yamanoimo), D. batatas I (Yamatoimo), and D. batatas II (Nagaimo)) (Table 2). It was found that D. japonica I (Jinennjyo) flour was the most suitable for bread making (bread height, $68.4 \mathrm{~mm}$; specific volume, $3.95 \mathrm{~cm}^{3} / \mathrm{g}$ ), yielding almost the same bread making properties as wheat flour. The appearance of $D$. japonica (Jinennjyo) flour bread is shown in Fig. 1. It was concluded that yam (D. japonica) (Jinennjyo) flour could be used for bread making as an alternative to wheat flour. With respect to the viscoelasticity of yam flour, yam (Jinennjyo) flour was found to be the most suitable for

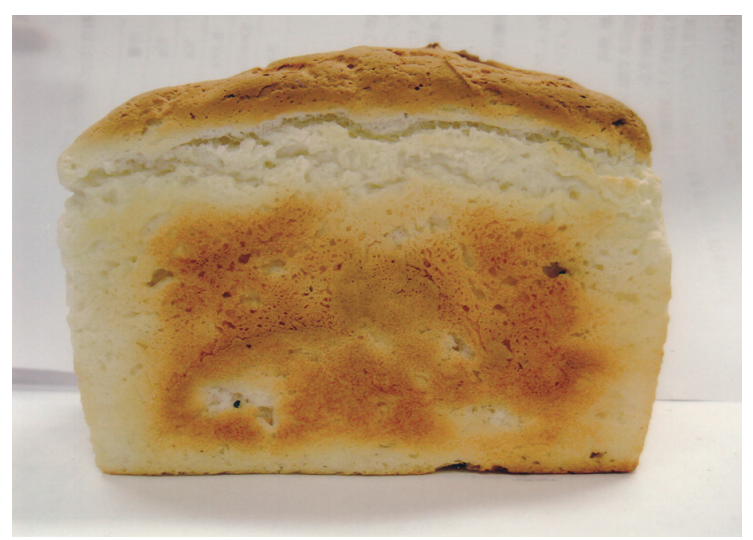

Fig. 1. Appearance of gluten-free bread baked with yam (Jinennjyo) flour.

Table 2. Properties of bread baked with yam flour.

\begin{tabular}{ccc}
\hline Yam flour & Bread Height $(\mathrm{mm})$ & Specific volume $\left(\mathrm{cm}^{3} / \mathrm{g}\right)$ \\
\hline Dioscorea japonica I (Jinennjyo) & $68.4_{\mathrm{a}}(2.3)$ & $3.95_{\mathrm{a}}(0.33)$ \\
Dioscorea japonica II (Yamanoimo) & $38.2_{\mathrm{c}}(3.0)$ & $2.41_{\mathrm{b}}(0.01)$ \\
Dioscorea batatas I (Yamatoimo) $_{\text {Dioscorea batatas II (Nagaimo) }}$ & $57.3_{\mathrm{b}}(1.3)$ & $3.80_{\mathrm{a}}(0.03)$ \\
Haruyutaka wheat flour $^{1}$ & $42.6_{\mathrm{c}}(0.1)$ & $3.00_{\mathrm{c}}(0.08)$ \\
\hline
\end{tabular}

Values represent means of two replicates with SD in parentheses.

Means followed by different letters in columns are significantly different at $\mathrm{P}<0.05$ according to Duncan's multiple range test.

${ }^{1}$ Seguchi, M. and Abe, M. (2004). Effect of leek (A. ampeloprasum L.) and scallion (A. chinense L.) on breadmaking properties. Food Sci. Technol. Res., 10, 479-482. 
bread making in place of wheat flour gluten. Next, the leavening mechanism of yam (D. japonica) (Jinennjyo) flour was assessed with respect to bread making. To determine the effect of yam components on bread making properties, yam was separated by dialysis into HMW and LMW fractions and the bread making properties of the HMW or LMW fractions were compared to that of yam flour.

Fractionation of yam (Jinennjyo) flour and analysis of yam components required for bread making Yam (Jinennjyo) flour (10.0 g) was dialyzed against a large amount of water overnight and separated into nondialyzable (HMW) $(9.3 \mathrm{~g})$ and dialyzable (LMW) fractions $(1.1 \mathrm{~g})$. Each of these fractions was used in bread making (Table 3). Individual HMW or LMW fractions did not exhibit good bread making properties. However, when the HMW and LMW fractions were mixed, good bread making properties (bread height, $64.2 \mathrm{~mm}$ and specific volume, $4.30 \mathrm{~cm}^{3} / \mathrm{g}$ ) were obtained (Table 3). It is thought that certain components in the LMW fraction are required for yam (Jinennjyo) flour bread making. It is known that yam (Jinennjyo) contains a high concentration of potassium $(12 \mathrm{mg} / 100 \mathrm{~g})$, and we were interested in determining whether potassium is involved in determining bread making properties. A baking test using the HMW fraction plus ash of the LMW fraction was performed that indicated that potassium had no effect on bread making properties (bread height, $47.0 \mathrm{~mm}$ and specific volume, 2.82 $\mathrm{cm}^{3} / \mathrm{g}$ ) (Table 3). Next, it was examined whether both HMW and LMW fractions were necessary for viscosity of yam flour/water mixtures.

Mixograph profiles of yam flour When flour and water are mixed in a mixograph bowl and form a creamy and homogenous dough, the amplitudes of the mixograph pin are small (Nakamura et al., 2008). Figures 2 A, B, and D show small amplitudes of the mixograph pin, which suggest a homogenous dough is obtained after a short mixing period. However, Figure $2 \mathrm{C}$ shows larger amplitudes due to minimal creaminess and discontinuity of the mixture. The homogeneousness of yam flour dough is important for obtaining

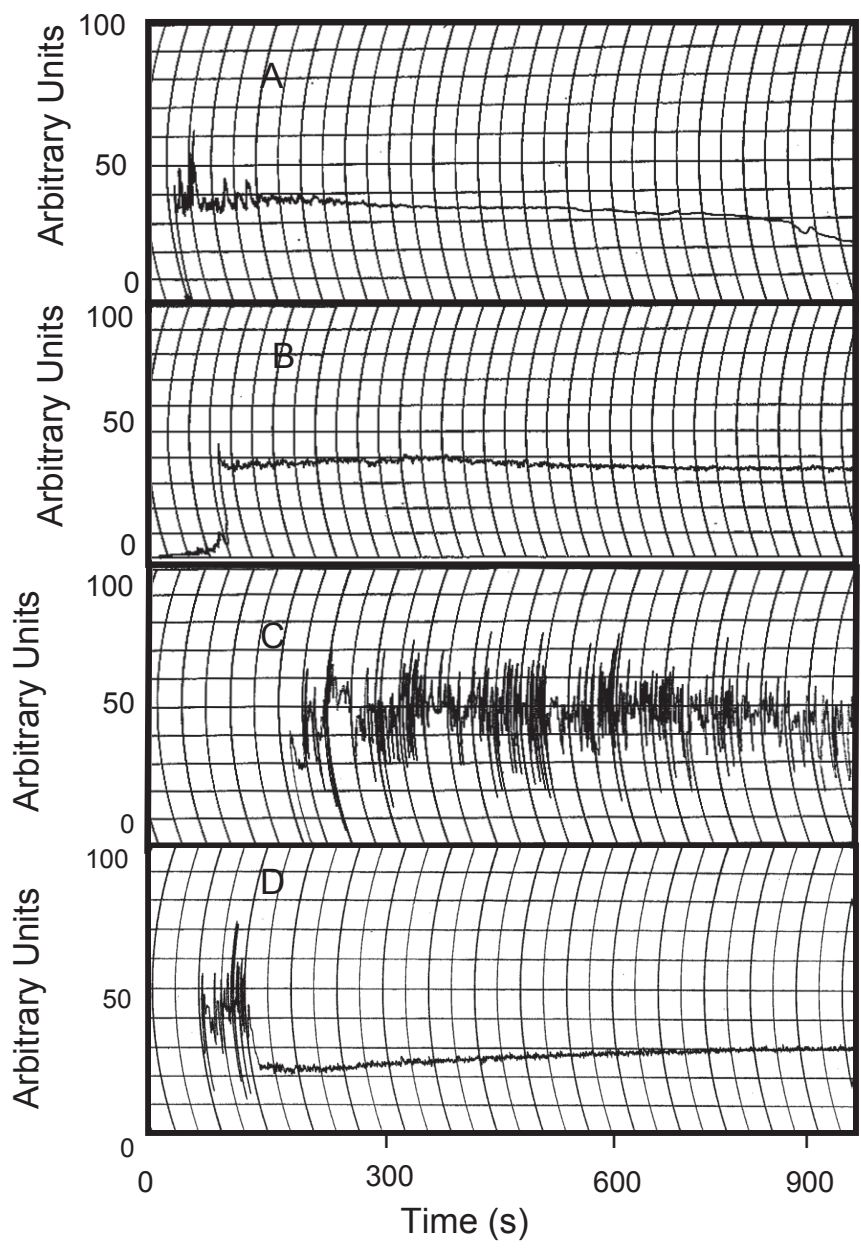

Fig. 2. Mixograph profiles of (A) wheat flour ( $10 \mathrm{~g} / 5.0 \mathrm{~mL}$ water), (B) yam (Jinennjyo) flour (10 g / $5.5 \mathrm{~mL}$ water), (C) HMW fraction (10 g / $5.5 \mathrm{~mL}$ water), and (D) HMW (9.45 g / $0.55 \mathrm{~g}$ LMW fraction/ $5.5 \mathrm{~mL}$ water).

Table 3. Effects of yam (jinennjyo) flour fractions on breadmaking properties.

\begin{tabular}{|c|c|c|c|}
\hline Fraction & Bread height (mm) & Specific volume $\left(\mathrm{cm}^{3} / \mathrm{g}\right)$ & $\begin{array}{l}\text { Bread crumb } \\
\quad L, a, b\end{array}$ \\
\hline Yam (Jinennjyo) flour & $61.8 \mathrm{a}(0.0)$ & $3.78 \mathrm{a}(0.00)$ & $\begin{array}{lll}78.7, & 24.2, \quad 37.8\end{array}$ \\
\hline HMW fra. & $22.8 \mathrm{~b}(0.4)$ & $1.47 \mathrm{~b}(0.04)$ & $71.2, \quad 11.8, \quad 25.6$ \\
\hline LMW fra. & $22.2 \mathrm{~b}(0.4)$ & $1.47 \mathrm{~b}(0.15)$ & $80.3, \quad 0.62, \quad 17.8$ \\
\hline HMW fra. + LMW fra. & $64.2 \mathrm{a}(2.0)$ & $4.30 \mathrm{a}(0.30)$ & $64.5, \quad 19.8,27.5$ \\
\hline HMW fra. + Ash & 47.0c (ND) & $2.82 \mathrm{c}(\mathrm{ND})$ & $78.7, \quad 12.8, \quad 30.4$ \\
\hline HMW fra + sugar subfraction & $33.3 \mathrm{~d}(4.1)$ & $2.08 \mathrm{~d}(0.60)$ & $91.2, \quad 12.3,29.1$ \\
\hline HMW fra + peptide subfraction & $56.2 \mathrm{c}(5.2)$ & $3.47 \mathrm{a}(0.09)$ & $82.6, \quad 12.1, \quad 26.5$ \\
\hline
\end{tabular}

Values represent means of two replicates with SD in parentheses.

Means followed by different letters in columns are significantly different at $\mathrm{P}<0.05$ according to Duncan's multiple range test.

ND; not determined. 
good bread making properties, namely, bread height (mm) and specific volume $\left(\mathrm{cm}^{3} / \mathrm{g}\right)$. The homogeneousness, based of mixograph profiles, of wheat flour dough was compared with that of yam (Jinennjyo) flour dough (Figs. 2-A and B). The homogeneousness of yam (Jinennjyo) flour dough was similar to that of wheat flour dough, although the ratio of flour to water differed between the yam and wheat flour dough. In the case of wheat flour, the ratio of flour to water was determined as $10 \mathrm{~g} / 5.0 \mathrm{~mL}$, rather than $10 \mathrm{~g} / 5.5 \mathrm{~mL}$, because the desired profile was not detected during the observation period at $10 \mathrm{~g} / 5.5 \mathrm{~mL}$. However, the amplitudes for both ratios were almost the same. As indicated in Figures 2-B and D, the mixograph profiles of yam flour dough and HMW/LMW fraction dough were almost the same; both types of dough exhibited a creamy, homogenous appearance immediately after mixing with small mixing amplitudes. However, the profile of HMW fraction dough (Fig. 2-C) differed from that of the other types of dough, having a larger mixing amplitude that may be due to heterogeneity of the dough. From these findings, it was assumed that heterogeneous HMW fraction dough would easily release gas produced by the yeast, resulting in poor bread making properties.

Separation of the LMW fraction into peptide and sugar subfractions Next, the peptide and sugar subfractions in the LMW fraction were separated by paper chromatography. Figure 3 shows the results of paper chromatography of the LMW fraction; the left and right sides are visualized using ninhydrin solution for peptides and AHP solution for sugars, respectively. The ninhydrin solution (left side) showed the main subfraction (from the original point to Rf 0.30) and traces amounts at $\mathrm{Rf} 0.55$ and 0.62 . In contrast, the AHP solution (right side) showed three main spots, Rf 0.46, 0.57, and 0.65 , of which Rf 0.57 would correspond to the $\operatorname{Rf}(0.55)$ of peptides. The LMW fraction was separated into the peptide (from the original point to Rf 0.30) and sugar (Rf 0.460.65 ) subfractions by paper chromatography. A large amount $(1.1 \mathrm{mg}$ ) of the LMW fraction was thus quantitatively subjected to thick paper (No. 590) chromatography in the same system. Yields of 0.48 and $0.37 \mathrm{mg}$ were obtained for the peptide and sugar subfractions, respectively. Bread making tests were then performed using the HMW fraction in combination with the peptide or sugar subfractions. The results indicated (Table 3) that addition of the peptide subfraction to the HMW fraction was more effective in improving bread making properties (bread height, $56.2 \mathrm{~mm}$; specific volume, $3.47 \mathrm{~cm}^{3} / \mathrm{g}$ ) than addition of the sugar subfraction (bread height, $33.3 \mathrm{~mm}$; specific volume, $2.08 \mathrm{~cm}^{3} / \mathrm{g}$ ).

It was determined from the mixograph profiles that a homogenous flour dough was not obtained with the HMW fraction alone (Fig. 2C), but was obtained with the combined

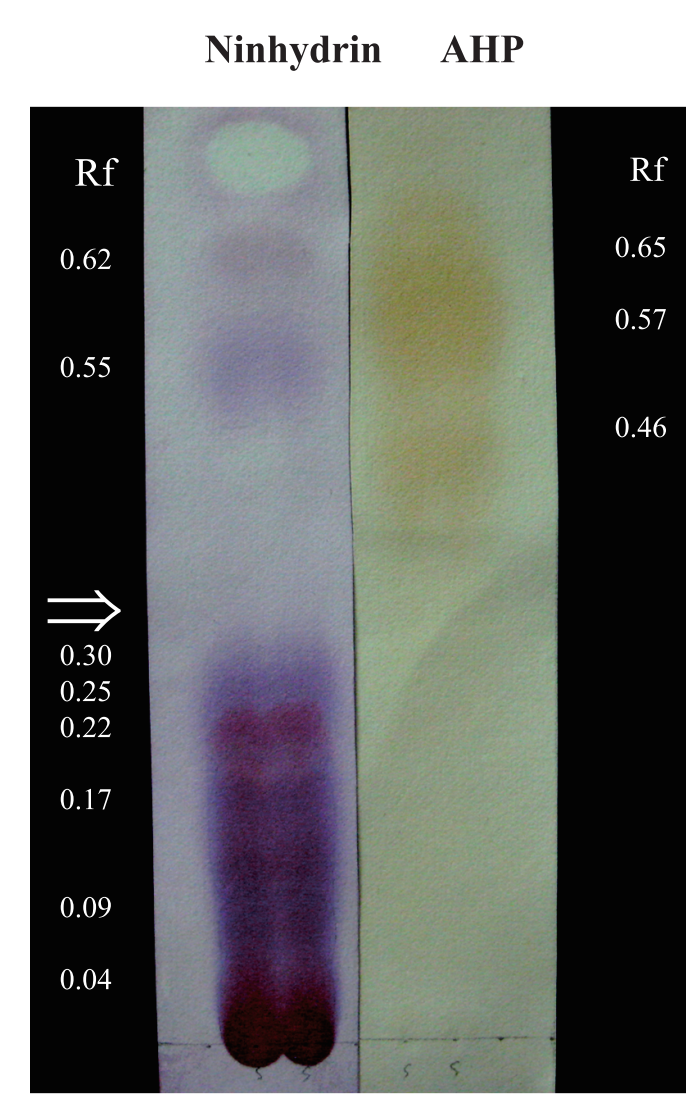

Fig. 3. Paper chromatography (pyridine/1-butanol/water $=4: 6: 3$ ) of yam flour dialyzable fraction (LMW). The left side is the peptide subfraction visualized using ninhydrin solution, and the right side is the sugar subfraction visualized using AHP solution.

HMW and LMW (Fig. 2D) fractions in the dough. In support of these findings, good bread making properties were obtained using the HMW- and LMW-fraction dough, but not the dough containing the HMW-fraction-alone. A heterogeneous and coagulated bread dough was obtained by adding water to the HMW fraction and other ingredients (yeast and sugar). However, when the LMW fraction was also added to the dough, we obtained a creamy and homogenous bread dough without coagulation. Because this homogenous bread dough did not leak gas, good bread making properties were obtained. It was further clarified that the peptide subfraction of the LMW fraction prevented the coagulation of the bread dough containing the HMW fraction, producing favorable bread making properties. The detailed mechanism of the function of the peptide subfraction remains unclear.

\section{Conclusions}

Good gluten-free bread baked with yam (Jinennjyo) flour was obtained. It is known that yam flour (Jinennjyo) is the most suitable for producing gluten-free bread. Trace levels of gluten (several mg) may be derived from wheat starch granules present in a single loaf, however, it will be below toxic levels of gluten $(10-50 \mathrm{mg}$ daily). However, in the 
future, it will be necessary to search other starch sources. Yam flour was fractionated into HMW and LMW fractions using dialysis, and bread was baked with the HMW or LMW fractions. Although the individual HMW or LMW fractions produced poor bread making properties, the combined HMW and LMW fractions provided favorable bread height $(\mathrm{mm})$ and specific volume $\left(\mathrm{cm}^{3} / \mathrm{g}\right)$. The LMW fraction was further separated into the peptide and sugar subfractions by paper chromatography, and bread was baked with the HMW fraction and the peptide or sugar subfractions. Good bread making properties were obtained using the HMW fraction and the peptide subfraction but not the HMW fraction and the sugar subfraction.

\section{References}

AACC International. (2000). Approved methods of the american association of cereal chemists, 10th Ed., Method 08-01, 46-10, American association of cereal chemists: St. Paul, MN.

Catassi, C. and Yachha, S.K. (2009). The epidemiology of cell disease. In "The science of gluten-free foods and beverages," ed. by E. K. Arendt and F. D. Bello. AACC International, Inc. St. Paul, Minnesota pp. 1-11.

Catassi, C. and Fasana, A. (2008). Celiac disease. Gluten-free cereal products and beverages. In "Celiac disease Gluten-free cereal products," ed. by E. K. Arendt and F. D. Bello. Academic Press Elsevier Inc. pp. 1-27.

Galliard, T., Bowler, P. and Towersey, P.J. (1989). Minor components of wheat starch and their technological significance. In "Wheat is unique," ed. by Y. Pomeranz. AACC International, Inc., St. Paul pp. 251.

Hou, W.C., Hsu, F.L. and Lee, M,H. (2002). Yam (Dioscorea batatas) tuber mucilage exhibited antioxidant activities in vitro. Planta Med., 68, 1072-1076.

Miyoshi, N., Nagasawa, T., Mabuchi, R., Yasui, Y., Wakabayashi, K., Tanaka, T. and Oshima, H. (2011). Chemoprevention of azoxymethane/dextran sodium sulfate-induced mouse colon carcinogenesis by freeze-dried yam sanyaku and its constituent diosgenin. Cancer Prev. Res. (Phila), 4, 924-934.

Nakamura, C., Koshikawa, Y. and Seguchi, M. (2008). Increased volume of Kasutera cake (Japanese sponge cake) by dry heating of wheat flour. Food Sci. Technol. Res., 14, 431-436.

Nozawa, M., Sato, S., Hatori, Y., Izawa, H. and Sagai, M. (2005). Effect of yam (Dioscorea batatas) treatments on suppression of blood pressure, and renal and vascular nitric oxide synthase expression in spontaneously hypertensive rats. J. Aomori Univ. Health Welf., 6, 369-378.

Omoruyi, F.O. (2008). Jamaican bitter yam sapogenin: potential mechanisms of action in diabetes. Plant Foods Hum. Nutr., 63, 135-140.

Seguchi, M. and Abe, M. (2004). Effect of leek (A. ampeloprasum L.) and scallion (A. Chinense L.) on bread making properties. Food Sci. Technol. Res., 10, 479-482.

Tsukui, M., Sato, H., Nagashima, T., Watanabe, T., Takano, K. and Kozima, T. (2001). Structure characterization of polypeptides of viscous glycoprotein from yam (Dioscorea opposita THUNB.) mucilage. Nippon Shokuhin Kagaku Kogaku Kaishi, 48, 578-585.

Tsukui, M. (2003). Analysis of properties and chemical structure of mucilage from yam (Dioscorea opposita THUNB). Food Preser. Sci., 29, 229-236.

Tsukui, M., Takagai, R., Yamaguchi, Y. and Kagawa S. (2005) Yamaimo nennshutsubutsu wo riyou shita sapurimennto no kaihatsu. Kanto Gakuin University, Society of Human and Environmental Studies, Bulletin, 4, 79-88.

Tsutsumi, C. and Nagahara, T. (1961). Effect of drying temperatures on the moisture determination of starches by oven drying method. Shokuryou Kagaku Kenkyu Hokoku, 15, 118-119.

Yoshida, Y., Takahashi, H., Kanda H. and Kanahama, K. (1976). Effect of seed tuber weights on the development of tubers and flowering spikes in Japanese yams (Dioscorea japonica) grown under different photoperiods and with plant growth regulators. $J$. Japan. Soc. Hort. Sci., 76, 230-236. 